\title{
R. Dappa, La scienza minima necessaria per contrarre il matrimonio nella dottrina e nella giurisprudenza rotale (can. 1096 CIC), Gliwice 2013, 205 ss.
}

Problematyka wad zgody małżeńskiej (kan. 1095-1103 KPK) doczekała się w kanonistyce licznych opracowań. W tej bogatej literaturze znajduje się jednak niewiele pozycji, zwłaszcza monograficznych, dotyczących ignorancji (kan. $1096 \$ \$ 1-2$ KPK). Taki stan wynika zapewne $\mathrm{z}$ faktu, iż w sądownictwie kościelnym sprawy o stwierdzenie nieważności małżeństwa sporadycznie są prowadzone $\mathrm{z}$ tytułu, o którym traktuje kan. $1096 \$ \$ 1-2$ KPK. Tematykę tę podjął ks. R. Dappa w monografii La scienza minima necessaria per contrarre il matrimonio nella dottrina e nella giurisprudenza rotale (can. 1096 CIC).

Rozpoczynając prezentację tej pozycji pragnę podkreślić, że w opracowaniu tym autor nie ograniczył się jedynie do ukazania dorobku współczesnej kanonistyki i judykatury rotalnej w tym obszarze, ale osadził podjętą tematykę w szerszym kontekście tak doktrynalnym, jak i systemowym. W omawianym opracowaniu bowiem przedstawił on rozwój myśli doktrynalnej w przedmiocie wiedzy minimalnej do zawarcia małżeństwa od zarania dziejów Kościoła. Czytając to dzieło nie trudno dojść do przekonania, że tak sprecyzowany projekt badawczy zadecydował w głównej mierze o strukturyzacji opracowania. W skład monografii weszło aż sześć rozdziałów.

Rozdział I zatytułowany Matrimonio in genere ma charakter wprowadzający. W tej części opracowania ks. R. Dappa ukazał wątki niejednokrotnie poruszane $\mathrm{w}$ kanonistyce, wiążące się $\mathrm{z}$ kanoniczną koncepcją małżeństwa. Uważam podjęcie poruszonej tematyki za 
pełni zasadne. Osadzenie bowiem problematyki pryncypialnej dla tego dzieła w takim kontekście, umożliwia czytelnikowi bardziej dogłębne zrozumienie problematyki ukazanej w monografii.

Rozważania ukazane w rozdziałach II i III mają charakter prawno-historyczny. W tej części opracowania autor przedstawił rozwój doktryny w kwestii wiedzy minimalnej do zwarcia małżeństwa od początków chrześcijaństwa aż do czasu promulgacji Kodeksu Jana Pawła II z 1983 r.

Pragnę podkreślić, iż analizy zawarte w rozdziale II Necessità di un minimo di conoscenza del matrimonio prima della codificazione Pio-Benedettina zostały przez ks. R. Dappa wpisane w szerszy kontekst. W swym namyśle bowiem nad zagadnieniem pryncypialnym dla tej pozycji nie ograniczył on się wyłącznie do przedstawienia rozwoju doktryny w interesującej go tematyce w okresie niemalże dwudziestu wieków historii Kościoła, ale omówił również dorobek prawa rzymskiego i germańskiego w materii. Taki sposób ujęcia należy uznać za w pełni przekonywujący, gdyż koncepty wypracowane we wspomnianych systemach prawnych zostały recypowane i dostosowane do założeń systemowych kanonicznego porządku prawnego.

W rozdziale III opublikowanym pod tytułem La norma nel periodo in cui era in vigore il Codice Pio-Benedettino ks. R. Dappa $\mathrm{z}$ jednej strony skoncentrował uwagę na szczegółowej wykładni kan. 1082 KPK z 1917 r., z drugiej zaś strony na kwestii dorobku ówczesnych komentatorów w kwestii wiedzy minimalnej do zawarcia małżeństwa. Pragnę zwrócić uwagę, iż autor nie ukazał jedynie poglądów poszczególnych kanonistów i audytorów rotalnych, lecz przedstawił tę tematykę z aspektu ujęć koncepcyjnych doktryny i judykatury rotalnej, wyszczególniając trzy kierunki: minimalistyczny, maksymalistyczny oraz pośredni. Co więcej, w obszarze badań dotyczących judykatury rotalnej w sposób szczególny skupił on uwagę na treściach zawartych w wyroku c. Sabattani wydanym w dniu 22 marca 1963 r., ponieważ w sentencji tej audytor rotalny odniósł się do związku zachodzącego pomiędzy ignorancją a błędem (s. 95). Temu problemowi ks. R. Dappa poświęci uwagę w rozdziale $\mathrm{V}$. 
Rozdział III wieńczy prezentacja przebiegu prac nad rewizją Kodeksu z 1917 r. W tej części opracowania autor przedstawił i poddał szczegółowej analizie poszczególne projekty regulacji dotyczących wiedzy minimalnej do zawarcia małżeństwa, wypracowane przez gremia pracujące nad nową kodyfikacją.

Rozdział następny pozostaje w ścisłym związku z poprzednimi. W tej części monografii bowiem ks. R. Dappa dokonał szczegółowej wykładni zapisu kan. $1096 \$ \$ 1-2$ KPK, prezentując stanowisko doktryny w kwestiach takich komponentów normatywnych, jak: wspólnota życia małżeńskiego, trwałość, heteroseksualność, skierowanie na zrodzenie potomstwa oraz seksualne współdziałanie.

Za tezę dyskusyjną uważam twierdzenie wyrażone w rozważaniach dotyczących podmiotu wiedzy minimalnej do zawarcia małżeństwa, w myśl której Kościół ze względu na sakramentalną godność małżeństwa proteguje godność konsensu małżeńskiego (s. 111). W moim przekonaniu, w kanonicznym porządku prawnym zgoda małżeńska jest protegowana nie tyle ze względu na sakramentalną godność, lecz ze względu na jej naturalną godność. W systemie kanonicznym bowiem małżeństwami legalnymi są nie tylko związki sakramentalne, ale również związki niesakramentalne.

Rozdział IV wieńczą rozważania dotyczące domniemania ujętego w kan. $1096 \S 2$ KPK.

Za bardzo interesujące należy uznać analizy teoretyczno-prawne przeprowadzone w rozdziale $\mathrm{V}$, dotyczące współzależności zachodzącej między ignorancją a błędem. W rozdziale tym bowiem ks. R. Dappa, analizując szczegółowo dorobek doktryny w tej materii, stanął na stanowisku, iż w zapisie kan. 1096 KPK znajduje aplikację zasada skodyfikowana w kan. 126 KPK dotycząca błędu co do substancji aktu. Wykazał on, iż dyspozycja kan. $1096 \$ 1$ KPK wskazuje na formę błędu prawnego dotyczącego natury aktu (s. 152).

Ostatni, szósty z rozdziałów został poświęcony problematyce dowodzenia ignorancji (La prova giudiziale dell'ignoranza). Swe rozważania ks. R. Dappa rozpoczął od ukazania nowszych rozstrzygnięć rotalnych w interesującej go kwestii. Pragnę podkreślić, iż podjęcie tej tematyki jest przede wszystkim interesujące ze względu na fakt, iż jak 
wykazał autor, po 1983 r. Rota Rzymska nie wydala żadnego wyroku z tytułu ignorancji. W takiej sytuacji ks. R. Dappa poddał analizie sentencje, w których wątek niewiedzy co do małżeństwa pojawił się ubocznie. Dysponując takim materiałem badawczym skupił on uwage na problematyce dowodzenia przez sędziego. Obiektem szczególnym zainteresowania stała się kwestia kryteriów dowodzenia. W tym kontekście wyróżnił on: kryterium psychofizyczne, kryterium wynikające z edukacji, kryterium przedmałżeńskie oraz kryterium pomałżeńskie.

Całość monografii poprzedza Wstęp oraz wieńczy Zakończenie. Pragnę podkreślić, iż zostały one napisane zgodnie z zasadami przyjętymi w pisaniu tego typu opracowań. W omawianym dziele znajduje się też obszerna Bibliografia.

Konkludując pragnę stwierdzić, iż w prezentowanej pozycji ks. R. Dappa podjął problematykę sporadycznie poruszaną w kanonistyce w głównej mierze ze względu na fakt, iż sprawy o stwierdzenie nieważności małżeństwa są niezmiernie rzadko rozstrzygane w sądownictwie kościelnym. Niemniej jednak prowadzenie badań w kierunku określonym w doktoracie jest konieczne, ponieważ określenie komponentów wiedzy minimalnej koniecznej do zawarcia małżeństwa ma istotne znaczenie nie tylko $\mathrm{z}$ aspektu prawa procesowego i materialnego prawa małżeńskiego, ale przede wszystkim $\mathrm{z}$ aspektu teoretyczno-prawnego. Tego typu dociekania bowiem pozostają w ścisłym związku z doktrynalnym namysłem nad istotą małżeństwa.

Treści zwarte w tej monografii należy uznać za istotny wkład w rozwój badań nad wadami zgody małżeńskiej. W przedstawionym studium ks. R. Dappa dokonał nie tylko dogłębnej i rzetelnej wykładni kan. 1096 $\$ \$ 1-2 \mathrm{KPK}$, ale ukazał także rozwój doktryny i judykatury rotalnej w okresie ponad dwudziestu wieków dziejów chrześcijaństwa. Co więcej, poruszoną tematykę, w sposób przekonujący, osadził w szerszym kontekście, jakim były dokonania prawa rzymskiego i germańskiego. Takie ujęcie pozwala czytelnikowi w pełni zrozumieć genezę ujęć normatywnych, które występują w obowiązującej kodyfikacji. 